WILLIAM SAYERS

Cornell University, Ithaca

ws36@cornell.edu

\title{
ETYMOLOGIZING DEPRECATORY REDUPLICATIVE COMPOUNDS OF THE TYPES FLIM-FLAM AND HIGGLEDY-PIGGLEDY (PART II)
}

Keywords: lexicogenesis, lexicography, compound words, etymology, disparagement

\begin{abstract}
Sample English reduplicative compounds on the model of flim-flam and higgledy-piggledy are analyzed for the interplay of formal features (alliteration, vowel alternation, rhyme), semantics (as parts and wholes), and obscure origins. Loans, new coinages, internal realignment, register, and affect are discussed. Inadequacies in earlier lexicographical, especially etymological, treatment are remedied.
\end{abstract}

To summarize the previously published introduction to this two-part study, English is rich in deprecatory reduplicative compounds, which may be grouped in two typological classes: 1) those with alliterating initial consonant(s) followed by a shift from front to back vowel in the generally similar second half of the compound, and 2) those with dissimilar initial consonant(s) but similar continuing and concluding sounds. ${ }^{1}$ These compounds belong to the understudied popular register of English and their semantics are frequently expressive of whimsy or obsessiveness, triviality, inconsequentiality, even duplicity and deceit. Other compounds enter the force field created by this category of words and over time experience effects of alignment. Efforts to establish satisfactory etymologies for the elements of the compounds (variously called slang, vulgar, obscene, jargon, or cant) are often perfunctory in standard lexicographical works. Satisfactory etymologies are offered for eight such compounds.

1 Part one of this study (Sayers 2018) appeared in Studia Linguistica Universitatis Iagellonicae Cracoviensis 135.2: 97-106. 
Shilly-shally: In an entry first published in 1914 and not yet fully updated, the OED defines shilly-shally in its adjectival use as 'vacillating, irresolute, undecided' (OED, s.v. shilly-shally). An idiom current between 1700 and 1875 had the forms "to stand shill-I, shall-I; to go shill-I shall-I; to stand at shilly-shally", all of which meant to be irresolute or undecided. As Congreve (1700: iii. i. 47) writes: "I don't stand shill I, shall I, then; if I say't, I'll do't". ${ }^{2}$ As concerns the origin of the phrase, the OED observes: 'At first written shill $I$, shall $I$, altered form of shall $I$, shall $I$... For the vowel-alteration compare dilly-dally, wishy-washy'. There is, however, no written evidence for an original shall I? shall I?

Reduplicative compounds of the type here adduced come in two sorts: with alliterating initial consonant(s), the remainder of the words being similar (shillyshally), or with consonantal uniformity and a vowel alternation (e.g. willy-nilly). Generally speaking, the $O E D$ tends to consider most of this class of compound as whimsical creations, onomatopoeic formulations, 'vocal gestures', and the like. The incorporation of a personal pronoun naturally makes for a special case. The OED to one side, the impression is often that the first element contains the semantic nucleus of the term and that the second is a playful variation on it, for affective purposes. In the $O E D$ analysis, the first shall is altered to shill in order to contrast with the anticipated second instance: shall I, shall I $>$ shill $I$, shall I. From the anxious repetition of a single interior question, the forms are said to evolve toward two opposed questions. In such a context, shill should, to all appearances, mean shall I not? In the vowel alternation that characterizes these compounds, a high, front vowel generally suggests fineness or small scale, a low back vowel, coarseness, large scale. How has the front vowel come to suggest negation, and why does the negation precede the affirmation? Here we may leave the OED commentary, with the provisional judgment: etymology unsatisfactory.

Shill once existed in English as a regular, non-modal verb (independently of slang to shill 'to act as a decoy or accomplice in a business or gaming matter'), although it is not mentioned by the OED in the discussion of shilly-shally (OED, s.v. shill, $\mathrm{v}^{2}$ ). The basic meaning was 'to separate' and the form is traced to one of Old English scylian 'to separate, part, remove', a hypothetical OE ${ }^{*}$ scielian, or Old Norse skilja. Attested from the eleventh century, the form seems to have been restricted to agricultural practice by the mid-seventeenth century: 'If there bee any sheepe that beginne to ragge ... yow are to make the sheapheard shill them out' (Best 1984: 22). Thereafter the term is confined to English dialect and the rural environment. Skilja, the Old Norse cognate of Old English scylian/scilian, also meant 'to part, separate, divide'. Attested figurative usages are, however, richer than its English counterparts and include 'to distinguish, discern, decide

Shilly-shally is not widely represented in English dialect, where it is found only as term of disparagement, the uncertainty now applied to the quality of goods or a person (Wright 1898-1905, 5.384). 
(in law), make a reservation'. ${ }^{3}$ The reflexive form skiljask was used of making up one's mind but also in the sense of 'to forsake, leave off'. It then seems plausible that shill I? shall I? originated in the context of decision-making: do I make a decision about a possible action, do I renounce it, or shall I carry it out? To modify the earlier phrasing in this note: the form evolves NOT from the anxious repetition of a single interior question but from a consideration of alternate courses of action, in a mode of uncertainty. The Norse verb, implanted in the Danelaw, may have influenced the semantics of Old English forms. Here may be recalled the earlier example of willy-nilly, from will I? nill I? Both these verbs, however, have unquestioned OE roots.

Once conjoined, shill I? shall I? was open to the analogical effects of other reduplicative compounds, resulting in the phonological modification and shift in stress that led to the form shilly-shally. Over time, the idiom with stand (which seems to have had a performative, self-staging dimension, as if indecision had a locus) was lost, and shilly-shally itself assumed status as a verb, while continuing as an adjective and noun. The OED's assumption of shill as a variation of shall seems unwarranted but shill was surely selected to provide semantic and phonological contrast to the modal shall. The latter feature would have furthered its subsequent entry into the host of formally reduplicative forms in English.

The essay now turns to compounds that are not formally true to the reduplicative models that have been examined thus far but nonetheless share many features with them, not least register, affect, and difficulties in the search for origins.

Jiggery-pokery: The OED defines jiggery-pokery as 'deceitful or dishonest manipulation; hocus-pocus, humbug' and reproduces what must be seen as a relatively late first attestation in an entry from a Wiltshire dialect glossary of 1893 (OED, s.v. jiggery-pokery, citing Dartnell, Goddard 1893: 86). This may in part explain the dictionary's cross-reference to Scots joukery-pawkery in lieu of any extended etymological commentary. Joukery, in turn, is defined as in Jamieson's Scots dictionary as 'dodging; underhand dealing, trickery, deceit' (Jamieson 1867; OED, s.v. joukery). The first recorded instance in Scots is considerably earlier than that of jiggery-pokery in English: 'Keip zour promes, and pretex na ioukrie be my Lorde of Cassillis writing', from 1562. ${ }^{4}$ Pokery has no discrete entry in the OED. It is not even subsumed under poke. At this juncture, it may be noted that southern English jiggery-pokery does not meet the usual criteria for disparaging reduplicative compounds, in that both the initial consonants of the two elements and their first vowels differ. On the latter count, the $i / o$ alternation is typical enough for one model of compound, that with

3 Relevant lexicographical works are An Anglo-Saxon dictionary (Bosworth, Toller 1921) and An Icelandic-English dictionary (Cleasby et al. 1957). The Dictionary of Old English has not yet reached the letter S but a listing of incidences of scylian is found in Dictionary of Old English, Old English Corpus (di Paolo Healy 1998).

4 Kennedy (1563), page reference cited in the OED as sig. iijv 
front to back vowel alternation. In the earlier attested Scots variant joukery-pawkery, although there is a vowel contrast, both are back vowels, which, along with the difference in initial consonant, takes the phrase even farther from the conventional model. Before determining the best vantage point from which to conduct a renewed etymological, or, more modestly, historical inquiry, it should also be noted that the initial consonants $j$ and $p$ argue against a derivation from Old Norse, while the ending -ery is suggestive of Old French and Anglo-French -erie ( $<$ Latin -arius). Evolving semantics must also be borne in mind.

In the following, the working hypothesis is that English jiggery-pokery, despite the late attestation, may represent a parallel to, rather than a derivative of, Scots jaukerypawkery. If precedence is given to the initial element (as generally determinative of such formations), the first question that now suggests itself is the possible relation to $j i g$ as a verb in the sense 'to move a thing with a light jerky motion; to jerk to and fro or up and down' (OED, s.v. jig, n. and v.). In addition to this definition the $O E D$ identifies jig as 'to sing or play as a jig.' The accompanying etymological note reads in part:

Closely related to jig n.. (q.v.), but not known so early. In some senses it approaches obsolete French giguer (15th cent.) to gambol, freak, sport, nasalized ginguer to leap, kick, wanton (which is apparently not related to Old French gigue); but this resemblance may be merely accidental, or due to parallel onomatopoeic influence, the large number of words into which jig- enters indicating that it has been felt to be a natural expression of a jerking or alternating motion.

The OED states that the entry for jig was first published in 1901 and has not yet been fully updated, although it is uncertain to what extent this caveat applies to the comments on origin. ${ }^{5}$ English jiggle may be plausibly seen as a regular formation on jig with the reiterative verbal suffix -le. To the above French forms giguer and ginguer may now be added Anglo-French gigeler 'to frolic' (Rothwell et al. 2005, s.v. gigeler). In a tangential development from the playing and sounds of the fiddle to more general kinetics, Old French gigeler is evidence of early semi-independent use in reference to general frolicking. A nominal form ${ }^{*}$ gigelerie or, with the two liquids collapsed, ${ }^{*}$ gigerie is quite plausible and is hinted at in Middle English gigeloterie 'lascivious conduct, harlotry' (cf. Middle English gigge 'loose or foolish woman'; Kurath et al. 2001, s.vv. gigeloterie, gigge).

To return to the concept of movement, the EDD complements the OED in offering examples of $j i g$ in various mechanical applications (Wright 1898-1905: 3.363-364, s.v. jig). Of greater interest in the present context, gige appears in Middle English not only as a designation for the fiddle (and in an idiom meaning to present foolish arguments') and as a screeching or creaking sound but also in the compound gig-mille, a rotating device for raising the nap on fabric (cf. whirli-gig from 1440). Although the last word surely remains to be said, English to jig, both dance and other repetitive up and down or side to side motion, seems to have its origins in the fiddle and the dancing it accompanied, as well as in the bowing movement of

\footnotetext{
5 The word jig is not attested in Scottish letters before 1700.
} 
the instrument. French gigue and its other Romance congeners are most plausibly traced to an Old Frankish import cognate with Old High German giga 'fiddle'. No root is suggested in standard lexicographical works, although a hypothetical Indo-European ${ }^{\star} g^{h} i-g^{h} i$ ('twitter'? 'screech'?) has independently been posited on the analogy of the clearly onomatopoeic root ${ }^{*} g^{h} a-g^{h} a$, meaning 'to cackle' (Köbler 2014, s.vv. $\left.{ }^{*} g^{h} a-g^{h} a,{ }^{*} g^{h} i-g^{h} i\right)$. In addressing the question of how jiggery - alone or conjoined with pokery - came to refer to deceit and trickery, the notion of (mechanical) contrivance will be recalled in the subsequent discussion of semantic development, momentarily deferred in favour of a discussion of pokery.

The surest point of reference here seems the two distinct notions of enclosure (as in 'a pig in a poke'), and thrusting and pushing ('poke a person'). The former is unproblematically traced to Old French poke, poque 'bag, pouch' (< Old Frankish), while the latter, as a verb, also has cognates in many Germanic languages and may have an unattested Old English antecedent $(O E D)$. While pocketing something could be preparatory to an act of fraud, this poke seems an unlikely source for pokery, as suggestive of deceit. More plausible is the verb in the sense of 'to thrust or push (a thing) in a specified direction with a sharp movement' (note, too, a narrower application: 'to potter about; to move or work in a desultory, ineffective, or dawdling way'). Just as the verb fiddle came to refer to small-scale movement of the hands in an obsessive and/or inconsequential way (cf. fiddle-faddle) but was later metaphorically extended to fraudulent small adjustments, e.g. 'to fiddle the numbers' (enter false data in an account), so, it might be contended, the kinetic verbs jig and poke, one in reference to vertical movements and the other to horizontal, but both limited in scale, were extended to contrived, concealed, and fraudulent activity - the equivalent of sleight of hand. This would have occurred only when the double-dactylic form jiggery-pokery was in place, the formal features of which would identify the phrase as deprecatory and thus assist in the semantic shift from physical to moral action. The foregoing discussion, however, is predicated on jiggery-pokery being a native form in southern English and not loaned from Scots, where, it will be recalled, a comparable jaukerypawkery is known a good three centuries earlier than the first attestation of the English form. The discussion now turns to this and other Scottish evidence.

As for the base component of the initial element of jaukery-pawkery, the SND notes the orthographically variant jawk and offers the definition 'to trifle, spend one's time idly, to dally, waste time, be easily diverted from the task on hand; to walk slowly' (Grant 1931-1975; DSL, s.v. jawk). Thus, jauk cannot, even provisionally, be viewed as a calque on English jig, save perhaps in its sense of questionable or inconsequential small-scale activity. Although the French suffix -erie continued active in Middle English formations and has here been added in conventional fashion, the Scottish national dictionary states that jouk is 'a Scottish word of uncertain origin'. ${ }^{6}$ With jauk/ jawk established as 'to pass one's time idly', we turn to pawk (var. pauk), defined as 'a trick, ruse, stratagem; a wile, blandishment'. Pawkerie is then 'trickery, slyness'?

${ }^{6}$ DSL, first attested in Douglas's translation of Virgil (1513).

7 Pawk $(y)$ has also been recorded from the dialects of northern England (Wright 1898-1905). 
However, the early Scots form jaukery-pawkery, thus understood, displays some tension in that the significations of the two elements are not complementary. We should have to imagine the motif of deceit overpowering that of laziness. This difficulty, if such it is, can be resolved by hypothesizing an earlier, unrecorded form. Scots jauk 'to dally' had a near-homonym, jouk 'to duck, dodge' but also 'to evade by trickery, to cheat, deceive, play false'. ${ }^{8}$ This dual signification, literal and figurative, is the lynchpin to the extension of the Scottish compound. Use of the verb jouk in *joukerie-pawkerie would align the two parts of the phrase in semantic terms (deceitful act) but at the cost of a less than perfect formal resemblance, in that both initial consonant $(j / p)$ and the subsequent vowels (ou/aw) differ. The latter inconsistency is remedied to some degree in the recorded form jaukery-pawkery.

The loan of Scots jawkerieljoukerie-powkerie into broader northern English comprised a number of stages, doubtless less orderly - over space and time - than as presented here. Firstly, Scots jauk was understood as jouk in its literal sense, 'to duck, stoop, dodge'. Since it had no obvious counterpart in English, a comparable kinetic verb, jig 'to move a thing with a light jerky motion', was used in its stead. Secondly, Scots pawkerie was seen as the equivalent of English pokerie, a plausible but not attested word. The resultant form jiggery-pokery is then also formally aberrant in having both initial consonants and following vowels that differ from one another, perhaps more a coincidence than a modeling on Scots in this respect. Although the failure to understand the discrete Scots meanings of the component words has resulted in lexical substitutions, the central semantics of Scots jaukerie-pawkery are strikingly retained: deceitful or dishonest manipulation, hocus-pocus, humbug.

In light of the conclusions that paired English jiggery and pokery must be assumed to have taken on figurative senses of contrivance and deceit at, or after, their union, and that Scots offers joukery and pawkery with the idea of trickery in their historically earliest known forms, the hypothesis of a separate English origin for jiggery-pokery must be abandoned in favour of a loan, or better, an ill-executed calque from Scots. Jouk 'trickery' was perceived as jauk 'jerk' and rendered in English with jig. Pawk 'mischievous action' was understood, in a process related to folk etymologizing, as poke 'thrust, push'. The nominal suffix -erie was replicated as -ery and the conjoined phrase, formally situated in a word-cluster of disparaging terms, continued the original Scots semantics, 'deceitful contrivance or manipulation'. Conceivably, users and listeners may have imagined jigging and poking as resulting in some kind of contrived, fraudulent arrangement. In summary, the $O E D$ is vindicated as concerns the origin of the English compound, jiggery-pokery, although the history is more complicated than there assumed. This said, sure etymologies for early Scots jauk, jouk, and pawk remain desiderata. Other formations in English also suggest but do not quite meet the formal criteria of reduplicative compounds, while appearing to show their influence. Three examples follow.

8 DSL, s.v. jouk. In the absence of other solid etymological candidates (see DSL), one may consider Scots Gaelic giùg 'cringing, flattery', giùgach 'bending awkwardly with the head to one's side' (Dwelly 1993, s.v.). 
Flibbertigibbet: In an entry that has 'not yet been fully updated (first published 1897)', the $O E D$ defines flibbertigibbet as 'a chattering or gossiping person; a flighty or frivolous woman' (from the mid-sixteenth century), 'the name of a devil or fiend' (from 1603), and as 'a nickname found in Walter Scott'. The etymological note is typical of the treatment offered in these early entries dealing with popular speech: a faintly disapproving or disparaging tone accompanied by little commitment to seeking a historical origin:

Etymology: Apparently an onomatopoeic representation of unmeaning chatter. The earliest form in our quots., flibbergib, is probably the original; the later expansions are of a kind commonly met with in imitative words. The ending may be due to association with gibbet (OED, s.v. flibbertigibbet).

The dictionary's conclusion as to origin must reflect its perception of an absence of anything suggesting the lexeme in Latin, Old or Middle English, Old French, or Anglo-French. And today, with our greatly enhanced lexicographical resources, we may well concur. Yet all too often onomatopoeia seems the last resort of the etymologist.

Old West and East Norse, whose descendants are Icelandic and Norwegian on the one hand and Danish and Swedish on the other, might seem an unlikely source for a judgmental term related to idle chatter but the sagas do not suffer garrulous fools gladly and there is a rich judgmental vocabulary descriptive of speech acts. To cite the better attested Old Norse-Icelandic forms (although the Old Danish carried to the Danelaw is a more likely source), fleipa (var. fleipra) meant 'to babble, chatter' (cf. Icelandic, Norwegian fleipa, Swedish flepa 'speak meaninglessly', related to English lip and Germanic cognates), while fleipr was the corresponding noun, 'babble, tattle'. From the same semantic field is geipa 'to talk nonsense' (cf. Swedish gipa 'maw'; related to English gap, gape, and cognates). ${ }^{9}$ We have no evidence for a Norse

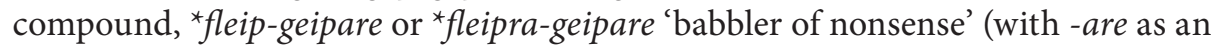
agent suffix) but in both formal and semantic terms it is fully plausible (see further below). Not too much in the way of special pleading (voiced to unvoiced labials) is called for in a reduction to flibbergib.

The semantics of flibbergib have changed little since its earliest recorded instance as 'chatterer' from the mid-sixteenth century and this obliges us to consider a long underground use of the term in Middle and early modern English. In a sermon by Hugh Latimer we read: 'These flatterers, and flybbergybes an other daye shall come \& clawe you by the backe ...' (Latimer 1549, cited from the OED). The association of idle speech with vice is even more explicit a half-century later in an anti-Catholic tract: 'Frateretto, Fliberdigibbet, Hoberdidance, Tocobatto were foure deuils of the round, or Morrice' (Harsnet 1603: x. 49). The use of the term for the name of a demon is unlikely to stem from any residual folk beliefs among the Anglo-Norse of the Danelaw

9 Cleasby et al. (1957), s.vv. Germanic cognates cited from Hellquist (1920). 
and is more representative of the lexical ingenuity of English ecclesiastics in devising outlandish names for non-Christian spirits. Demonological onomastics is deserving of more attention! Another later but equally pointed application of the term is to reprehensible behaviour among women ('a flighty or frivolous woman', OED), as is very frequently the case with terms of disparagement in English.

As concerns the formal elements of flibbertigibbet and its likely evolution from flibbergib, the OED's commentary is still relevant. English popular speech is marked by reduplicative forms that suggest not only reiteration but, in human terms, slight obsession. To the extent that these terms reward investigation, it is often seen that the elements had discrete origins and were phonetically aligned after their fusion. Thus, Old Norse fleipa and geipa may have reached Anglo-Norse independently, to be combined there on an established English model. Such realignment reduces transparency and increases the distance from the original semantics, as the words move into a different formal and affective register. In the modern English form, flibbertigibbet, with its addition of the ostensisbly adjectival suffix -ty, the uniform vocalism in $i+e$ and consonantism in $-b b$ - can be ascribed to this adaptive process. The adjective flibberty-gibberty 'flighty, frivolous, senseless' from $1879(O E D)$ takes the leveling a step farther.

To derive English flibbertigibbet from a pair of early medieval Norse words rather than accept the OED's dismissive recourse to phonic imitation is perhaps only to refer the problem back to a point - proto-Germanic? proto-Indo-European? - at which the evidence disappears. Today, the search for ultimate origins smacks of nineteenth century nationalism. A word's life and history, its interaction with one or more cultures, should surely interest us more. Yet English etymology continues to have readers, if few practitioners. Etymological commentary is expanding in the OED Online and it is to be hoped that the popular speech of past times will escape both the earlier taint of class prejudice and the trace of editorial proscriptiveness, and receive its due share of scholarly attention in the republic of words. Even the most fanciful-looking or -sounding, flibberty-gibberty word deserves a close but sympathetic look.

Whipper-snapper: In an entry last updated in 1923, the OED defines whippersnapper as 'a diminutive or insignificant person, esp. a sprightly or impertinent young fellow (OED, s.v. whipper-snapper). Under 'Etymology' the entry tentatively continues: '? A jingling extension of ${ }^{*}$ whip-snapper, a cracker of whips ... on the model of the earlier snipper-snapper'. The earliest attestation of the term, from 1674, however, limns a darker picture: 'Have a care of Marlbrough Downs, there are a parcel of whipper Snappers have been very busie there of late.' ${ }^{10}$ This said, the dictionary would seem to have taken its cue from the two and half decades later New dictionary of the canting crew: 'Whipper-snapper, a very small but sprightly Boy' (B.E. 1699, s.v. whipper-snapper).

10 Head (1674, sig. $\mathrm{C}^{\mathrm{v}}$ ) in the OED designation. 
In all this the $O E D$ appears to take whip at face value, an instrument for, or the action of, flogging. But the context in which whipper-snapper appears in this early dictionary of slang also includes the verb phrase whip off, defined as 'to steal, to drink cleverly, to snatch, and to run away'. Compare the entry for snapt: 'taken, caught'. 'Drinking cleverly' may be imagined as getting one's mark inebriated but not oneself, avoiding picking up the tab, etc. The remainder of the definition makes clear that the whipper-snapper is not a wielder of whips but a nimble cut-purse, pick-pocket, petty thief. As with other reduplicative compounds in English (whose elements may have distinct origins), internal or end rhyme, or alliteration give the compound a more memorable rhetorical turn. ${ }^{11}$

The satirist Thomas Brown's Amusements for the meridian of London is replete with low-life scenes and we find the contrast: 'A Grave Old Gentleman ... thus repremanded our Saucy Whipper-Snapper' (Brown 1700: xi, 136). A passage in Walter Scott a century and a quarter later encourages the speculation that it was in the environment of the courts, with its mix of criminals, bailiffs, barristers, and judges - and the interpenetration of their vocabularies - that the whipper-snapper was "decriminalized", turned from a young purse-snatcher into a lawyer's errand boy: 'A whipper-snapper of an attorney's apprentice, ... I'll teach him to speak with more reverence of the learned professions' (Scott 1827: 2.3.91). The underclass term could have been adopted by men about town and then gradually gained in respectable social currency, while still being a chic, vogue word. Subsequently, usage becomes even more generalized, and whipper-snapper is even used of cleverly designed objects and mechanisms. The ingroup semantics - whip 'to steal', snap 'to catch up' - are now overwritten and the common valences of the words yield the image of a snapping whip, any incongruity in this as characteristic of male adolescents being passed over. This evolution is typical of many slang words of eighteenth-century London. ${ }^{12}$ The development of whipper-snapper and similar instances may be judged to be the results of semantic melioration, the popular designation of an agent moving up the social scale toward quasi-respectability. Here, earlier boldness of action (open theft) has been narrowed to boldness of speech (opening one's mouth before one's social superiors). Pejoration is an equally possible outcome of descriptors on the social and semantic move, when they begin to be used judgmentally.

Gandy-dancer: 'railroad maintenance worker'. The OED defines gandy-dancer as 'a railroad maintenance worker', identifies the word as American slang, and calls the origin 'uncertain'. ${ }^{13}$ The earliest attestation is from 1923: 'A "gandy dancer" is

11 The term appears to have moved from urban to rural speech, since whipper-snapper is defined, inter alia, as 'cheat' in the EDD (Wright 1898-1905: 6.464).

12 See Sayers (2010, 2016ab, and other lexical studies by the author).

$13 \mathrm{OED}$, s.v. gandy dancer. The dictionary states that the entry has not been fully updated since its first publication in 1972. The 'origin unknown' is echoed in The America heritage dictionary of the English language (2016, s.v. gandy dancer). 
a man who works on the railroad track tamping ties' (Anderson 1923: vi, 93). A more scholarly consideration is found in an academic journal from a decade later: 'Gandy dancer, section hand (from the rhythmic up-and-down motion of workers pumping a handcar)' (Simons 1933: 26). Two kinds of repetitive activity are then identified as a possible matrix for the term.

There is no tradition in English of dancer entering into compounds with the sense of the manipulation of a tool or instrument. Nor does gandy exist in its own right in standard English (see further below). The most common sources of contemporary English vocabulary (Old English, Old Norse, medieval Norman and Anglo-French) are either ruled out by the late appearance of the term or (in the case of Middle Dutch, Middle Low German) by what is known of the later spread of industrialization. One might concoct a resemblance, say in pseudo-French ${ }^{*}$ gandin-danseur 'dancing dandy', but all evidence for such a loan is lacking. This fabricated compound and its English equivalent do, however, suggest a possible loan from another area of activity: sea-faring. The dandy was a small capstan used in hoist the trawl on fishing boats in the age of sail (Smyth 1867, s.v. dandy). The bars of the capstan might be likened to the bars of the pivot-mounted beam of a railway handcar but the slow trudge around the capstan has little resemblance to the vertical pumping of the handcar. A loan from such a source would also entail some phonological differentiation (dandy $>$ gandy), to produce the effect seen in roughly similar compounds of the hurdy-gurdy type.

It has also been proposed that gandy is to be traced to the name of a tool manufacturer, on the model of proper names being turned into common nouns and verbs, e.g. boycott, lynch. Products of such a company are listed in an account from 1945: 'Gandy dancer - track labourer. Name may have originated from the ganderlike tremulations of a man tamping ties, or from the old Gandy Manufacturing Company of Chicago, which made tamping bars, claw bars, picks, and shovels. ${ }^{14}$ But in addition to instruments used to tamp down ballast or replace damaged ties, the company would also have manufactured the lining bars employed by teams of men acting in unison to heave the rails into alignment after they had been raised by the plough, prior to the deposit of fresh ballast (crushed stone). Although perhaps a bit of a stretch, six men beside a rail, making the same moves, partnered with the upright bars, may have recalled a chorus line of dancers. However attractive this derivation and the imagery that might accompany it, railway historians and steam buffs have been unable to discover any documentation that would establish the existence of a Gandy Company. ${ }^{15}$

Irish immigrants were numerous in early section gangs and the idea of a source for gandy-dancer in Gaelic has been ventured but never, to the best of my knowledge, seriously pursued. In modern Irish grean and its variant grian mean 'gravel', both in the sense of the stone found at the bottom of the sea, a lake or river and as used in the contraction of a foundation (Dinneen 1927, s.v. grian). It would be an appropriate

14 Hubbard (1945: 344; cited in Cassidy 1985-2013, s.v. gandy dancer).

15 Gandy dancer: https://en.wikipedia.org/wiki/Gandy_dancer. 
choice to designate railway ballast in Irish. A man tamping ballast with a shovel would replicate the movements seen in Irish step dancing (including the rigid upper body), so that the comic invention of an Irish wag could have been ${ }^{*}$ grean-damhsóir 'gravel dancer' (approx. phonetic valence for an English ear: /grandowsor/). ${ }^{16}$ In the Englishing of this term, grean would have been recast on the model of English dialect gandy 'braggart, boaster, chatterer, idler' (via an intermediary grandy?), so that the internal rhyme gan-/dan- was effected and the word brought into line with similar reduplicative and reiterative compounds (Wright 1898-1905: 2.553, s.v. gandy). In some parts of Britain gander meant not only to walk like a goose but also to wander about, and this idea, too, may have attached itself to these itinerant workers, whose very job was to advance in goose-like fashion.

Gandy-dancer seems to have been a lightly disparaging or dismissive term, without having been wholly accomodated among the redupicative compounds as ${ }^{*} g a n d y$ $d a n d y$. After the great era of railway construction, railway maintenance involving ballast replacement was always seasonal work, and extra gangs moved about, living in boxcars near the stretch of track being repaired. Thus the connection with men on the move, the hobos of the past century.

In conclusion, eight English compound words, and in relevant cases their constituent parts (where the first element may be said to take the lead), have been provided with plausible etymologies (without recourse to onomatopoeia), remedying some slight neglect on the part of the $O E D$, which is often revealed to be dismissive toward this helter-skelter group of words. In the histories of the words examined, pejoration is a more common development than melioration as concerns semantics and affect. Reduplicative compounds of the type higgledy-piggledy - to take a double-dactyl example that embodies most of their salient features - are seen (1) to meet one of two sets of formal criteria, centered on consonant alliteration or vowel alternation, (2) to be invested with semantics that locate them among terms of none-too-severe moral judgment (often in extended figurative meanings), and (3) to belong to a popular speech register with a dismissive or censorious affect. In this phono-semantic environment, high front vowels are suggestive of small scale and fineness, low back vowels, of large scale and coarseness, in terms for deceitful action, perhaps the deception and its exposure, respectively. An awareness among speakers of English of this group of words, distinguished by its fixed phonological and congruent semantic features, has resulted in other look-alike compounds being "nudged" toward alignment in select respects.

16 On the model of the Irish phrase ag déanamh gainmhe 'to haul sand' (lit. 'at the working/ doing of sand'; Dinneen 1927, s.v. gaineamh), one could imagine a phrase ag déanamh griain 'working with gravel' and a derivative formation grean-déanta 'gravel works', which could also have generated, more phonologically than semantically (as with the dancer image), the phrase in question. 


\section{References}

The American heritage dictionary of the English language. 2016. [ $5^{\text {th }}$ edition]. Boston.

Anderson N. 1923. The hobo: The sociology of the homeless man. Chicago.

B.E. 1699 = B.E. was the nom de plume of the seventeenth century compiler; his true identity has not been determined.

Best H. 1984. The farming and memorandum books of Henry Best of Elmswell, 1642. London.

Bosworth J., Toller T.N. (eds.). 1921. An Anglo-Saxon dictionary. Oxford.

Brown T. 1700. Amusements serious and comical. London.

Cassidy F.G. (ed.). 1985-2013. Dictionary of American regional English. Cambridge.

Cleasby R., Vigfússon G., Craigie W.A. (eds.). 1957. An Icelandic-English dictionary. [2 ${ }^{\text {nd }}$ edition]. Oxford.

Congreve W. 1700. The way of the world. London.

Dartnell G.E., Goddard E.H. 1893. A glossary of words used in the county of Wiltshire. London.

Dinneen P.S. (ed.). 1927. Foclóir Gaedilge agus Béarla - An Irish-English dictionary. Dublin.

DSL = Dictionary of the Scots language. 2014. [www.dsl.ac.uk].

Dwelly E. (ed.). 1993. The illustrated Gaelic-English dictionary. [reprint]. Edinburgh.

EDD = Wright 1898-1905.

Grant W. (ed.). 1931-1975. The Scottish national dictionary. [= SND]. Edinburgh.

Harsnet S. 1603. A declaration of egregious popish impostures. London.

Head R. 1674. Jackson's recantation, or, The life \& death of the notorius high-way-man, now hanging in chains at Hampstead: Delivered to a friend, a little before execution; wherein is truly discovered the whole (...). London.

Hellquist E. (ed.). 1920. Svensk etymologisk ordbok. Lund.

Hubbard F.H. 1945. Railroad Avenue. New York.

Jamieson J. (ed.). 1867. Jamieson's dictionary of the Scottish language. Edinburgh.

Kennedy Q. 1563. The Ressoning which was betwix the Abbots of Crossraguell and John Knox. Edinburgh.

Köbler G. (ed.). 2014. Indogermanisches Wörterbuch. [5 ${ }^{\text {th }}$ edition; www.koeblergerhard.de/ idgwbhin.html].

Kurath H. et al. (eds.). 2001. Middle English dictionary. [= MED]. Ann Arbor.

Latimer H. 1549. The seconde sermon (...) preached before the kynges maiestie. London.

$O E D=$ Oxford English dictionary. OED online. 2016. [www.oed.com].

di Paolo Healey A. (ed.). 1998. Dictionary of Old English, Old English Corpus. Ann Arbor.

Rothwell W. et al. (eds.). 2005. Anglo-Norman dictionary. [= AND; $2^{\text {nd }}$ edition]. London.

Sayers W. 2010. Some 'Alsatian' etymologies from eighteenth-century London. - Notes \& Queries 57: 79-83.

Sayers W. 2016a. English etymologies from the popular register (I). - Studia Linguistica Universitatis Iagellonicae Cracoviensis 133.3: 171-181.

Sayers W. 2016b. English etymologies from the popular register (II). - Studia Linguistica Universitatis Iagellonicae Cracoviensis 133.4: 259-267.

Sayers W. 2018. Etymologizing deprecatory reduplicative compounds of the types flim-flam and higgledy-piggledy (I). - Studia Linguistica Universitatis Iagellonicae Cracoviensis 135.2: 97-106.

Scott W. 1827. The surgeon's daughter. - Chronicles of the Canongate. [2 vols.]. Edinburgh.

Simons H. 1933. A prison dictionary (expurgated). - American Speech 8: 22-33.

Smyth W.H. (ed.). 1867. The sailor's word book. London.

SND = Grant 1931-1975.

Wright J. (ed.). 1898-1905. The English dialect dictionary. [= EDD; 6 vols.]. London. 